\title{
miR-92a-3p regulates trypsinogen activation via Egr1 in AR42J cells
}

\author{
XUEMING ZHANG ${ }^{1}$, BO GAO $^{1}$, YANG HUANG ${ }^{1}$, YONG ZHANG $^{2}$, ZHITUO LI $^{1}$, \\ DALI ZHAO $^{1}$, BIAO MA ${ }^{1}$, DONGBO XUE ${ }^{1}$ and WEIHUI ZHANG ${ }^{1}$ \\ ${ }^{1}$ Department of General Surgery, The First Affiliated Hospital of Harbin Medical University, \\ Harbin, Heilongjiang $150001 ;{ }^{2}$ Department of Hepatopancreatobiliary Surgery, \\ Weifang Traditional Chinese Medicine Hospital, Weifang, Shandong 261041, P.R. China
}

Received February 17, 2019; Accepted July 15, 2019

DOI: $10.3892 / \mathrm{mmr} .2019 .10673$

\begin{abstract}
Acute pancreatitis (AP) exhibits high morbidity and mortality rates. The onset of AP is characterized by early trypsinogen activation.The present study aimed to investigate the expression of microRNA (miR)-92a-3p and early growth response protein $1(\mathrm{Egrl})$, and the effect of miR-92a-3p on trypsinogen activation in the pancreatic exocrine cell line AR42J. mRNA and miRNA microarrays were used to identify differentially expressed mRNAs and miRNAs in AR42J cells. A miRNA-mRNA network was constructed using bioinformatics software, and Egrl and its regulated miRNA subnetworks were identified by reviewing previous literature. The results suggested that miR-92a-3p could bind to Egrl 3 'untranslated region sequence. Subsequently, miR-92a-3p mimic and inhibitor were used to transfect AR42J cells. Following transfection, reverse transcription-quantitative PCR and western blotting were performed to detect Egrl expression. Furthermore, AR42J cells were cotransfected with miR-92a-3p inhibitor and small interfering (si)-Egr1. The trypsinogen activation rate of AR42J cells was measured by flow cytometry. Microarrays and bioinformatics results indicated that Egrl may be a target gene of miR-92a-3p. In addition, the present study suggested that miR-92a-3p downregulated Egrl in vitro and that miR-92a-3p and Egr1 expression was associated with trypsinogen activation. Furthermore, miR-92a-3p inhibitor reversed the effect of si-Egr1 on trypsinogen activation. In conclusion, miR-92a-3p may negatively regulate the activation of trypsinogen in AR42J cells via Egr1.
\end{abstract}

Correspondence to: Professor Weihui Zhang, Department of General Surgery, The First Affiliated Hospital of Harbin Medical University, 23 Youzheng Street, Harbin, Heilongjiang 150001, P.R. China

E-mail: zhangweihui626@hotmail.com

Key words: acute pancreatitis, miR-92a-3p, trypsinogen activation, AR42J, early growth response protein 1

\section{Introduction}

Acute pancreatitis (AP) is a common acute abdominal disease with high mortality and mortality rates. In the US, 220,000 patients with AP were hospitalized in 2013; of these cases, 1,661 were fatal (1). Additionally, there were also reports that the overall mortality rate in patients with acute pancreatitis was $\sim 5 \%$, with the mortality rate in patients with necrotizing pancreatitis $\sim 17 \%$ (2). At present, the pathogenesis of AP remains unclear; however, trypsinogen activation is considered as the first step in the development of AP (3). Dawra et al (4) hypothesized that activation of trypsinogen in acinar cells results in the death of acinar cells, with this process ultimately leading to pancreatic damage. The rat pancreatic acinar cell line AR42J secretes digestive enzymes and has therefore been widely used as an in vitro model of AP (5). Ma et al (6) used taurolithocholic acid 3-sulfate (TLC-S) to significantly induce trypsinogen activation in AR42J cells, and identified differentially expressed protein kinases by microarray analysis. Furthermore, Yang et al (7) reported that the JNK signaling pathway can promote trypsinogen activation. Although the development of AP is associated with gene regulation, it has been reported that changes in certain genes (TMEM173, XIAP, BHLHA15, CTSB) affect the severity of AP (8-12). Early growth factor 1 (Egrl) is an immediate early gene that contains three zinc finger domains (13). The expression level of Egrl mRNA increased after 30 min of AP model establishment (14), whereas early pancreatitis may be caused by trypsinogen activation (15). In addition, reduced level of inflammation was measured in an Egr1-knockout mouse model of AP (16). These data confirmed the role of trypsinogen activation and Egrl in AP and suggested novel targets that may also influence the treatment of the disease.

MicroRNAs (miRNAs) are small single-stranded RNAs (21-25 nucleotides in length) that are relatively conserved in biological evolution. Although these molecules do not encode proteins, they mediate numerous cellular processes (17). Previous studies reported that certain miRNAs are associated with AP. For example, miR-216a upregulation promotes the development of AP via the Akt and TGF- $\beta$ pathway in mice (18), and miR-155 upregulation can inhibit zonula occludens-1 expression and aggravate AP (19). miRNAs can 
downregulate gene expression by binding to complementary sites of target mRNAs, and subsequently degrade or inhibit these mRNAs (20). Based on the negative regulation of mRNAs by miRNAs, the present study aimed to identify the mRNAs regulated by miRNAs that could affect trypsinogen activation. According to miRNA and mRNA microarrays, the results from the present study suggested that the expression of miR-92a-3p and Erg1 was decreased and increased, respectively, in AR42J cells treated with TLC-S. In addition, the TargetScan tool, which could predict the binding of miRNA seed regions to mRNAs, identified that miR-92a-3p may bind to the 3'untranslated region (UTR) sequence of Egr1 mRNA. Since our previous research (unpublished data) reported that small interfering (si)-Egrl can reduce trypsinogen activation, the present study investigated whether miR-92a-3p could mediate trypsinogen activation in AR42J cells by modulating Egr1.

\section{Materials and methods}

Cell culture and mRNA and miRNA microarrays. The AR42J cell line was obtained from The Cell Bank of Type Culture Collection of the Chinese Academy of Sciences. Cells were cultured in DMEM (Gibco; Thermo Fisher Scientific, Inc.) supplemented with 10\% FBS (Gibco; Thermo Fisher Scientific, Inc.), $100 \mu \mathrm{g} / \mathrm{ml}$ streptomycin and $100 \mathrm{U} / \mathrm{ml}$ penicillin (Beyotime Institute of Biotechnology), and placed at $37^{\circ} \mathrm{C}$ in a humidified incubator containing $5 \% \mathrm{CO}_{2}$. The cells in the TLC-S group were treated with $200 \mu \mathrm{M}$ TLC-S (Sigma-Aldrich; Merck KGaA) for $40 \mathrm{~min}$ at $37^{\circ} \mathrm{C}(21,22)$, whereas cells in the control group were left untreated. Total RNA was extracted from cells using TRIzol ${ }^{\circledR}$ reagent (Invitrogen; Thermo Fisher Scientific, Inc.). Gene expression analyses (rat microarray v2.0; cat. no. Agilent-062716; Agilent Technologies, Inc.) and miRNA expression analyses (Affymetrix ${ }^{\circledR}$ GeneChip ${ }^{\circledR}$ miRNA 4.0 Array; cat. no. 902446, Affymetrix, Inc.; Thermo Fisher Scientific, Inc.) were performed by BioCloud, Inc. (Iyunbio).

Integrated analysis of miRNA-mRNA data and literature review. Gene names were integrated by referring to the abbreviations in the Rat Genome Database (https://rgd.mcw.edu/). Differences in mRNA/miRNA expression profiles between RNA samples from TLC-S-treated cells and RNA samples from control cells were analyzed using Student's t-tests and fold change (FC) assessment. Differentially expressed mRNAs were defined as those with a t-test false discovery rate $<0.05$ and $|\log (\mathrm{FC})|>1$. Differentially expressed miRNAs had a FC $>1.5$ or FC $<2 / 3$. TargetScan version 7.2 (http://www.targetscan.org) was used to predict the differentially expressed miRNA target genes. Furthermore, to establish a miRNA-mRNA regulatory network, Cytoscape software (version 3.6.1; https://cytoscape. org/) was used to identify the downregulated miRNAs and the upregulated target gene mRNAs. To obtain potentially valuable mRNAs, a literature review was performed in order to determine the association between mRNAs from the regulatory network and AP. First, a literature review algorithm was designed using Perl 4 software (http://www.perl.org/). Then, data from the literature were retrieved from the PubMed database (https://www.ncbi.nlm.nih.gov/pubmed/) using ActivePerl 5.16.2 software (ActiveState Software, Inc.), and titles and abstracts from the literature were searched using the keywords 'acute pancreatitis' and the mRNAs involved in AP were identified. Subsequently, the number of statistical documents was determined. Eventually, the target literature was manually screened to ensure the accuracy of the research content.

Cell transfection experiments. AR42J cells ( $1 \times 10^{5}$ cells) were seeded into six-well plates in complete DMEM and cultured overnight at $37^{\circ} \mathrm{C}$. Medium was removed and Lipofectamine 2000 (Thermo Fisher Scientific, Inc.) was used for cell transfection according to manufacturer's instructions. Cells were transfected with miR-92a-3p mimic, miR-92a-3p mimic-NC, miR-92a-3p inhibitor, miR-92a-3p inhibitor-NC, si-Egr1 and si-Egr1-NC (Shanghai GenePharma Co., Ltd.) at final concentrations of $50 \mathrm{nM}$ using $0.25 \%$ Lipofectamine 2000. After 4-6 h of transfection, the culture medium was replaced with fresh medium, and then the cells were collected by continuous culture for $48 \mathrm{~h}$. Each transfected group was then treated with $200 \mu \mathrm{M}$ TLC-S at $37^{\circ} \mathrm{C}$ for $40 \mathrm{~min}$ before collecting the cells. The sequence of the oligonucleotides used were as follows: miR-92a-3p mimic, 5'-UAUUGCACU UGUCCCGGCCUGGGCCGGGACAAGUGCAAUAUU-3'; miR-92a-3p mimic-NC, 5'-UUCUCCGAACGUGUCACG UTT-3'; miR-92a-3p inhibitor, 5'-CAGGCCGGGACAAGU GCAAUA-3'; miR-92a-3p inhibitor-NC, 5'-CAGUACUUU UGUGUAGUACAA-3'; si-Egr1, 5'-CCAGGACUUAAAGGC UCUUTTAAGAGCCUUUAAGUCCUGGTT-3'; si-Egr1-NC, 5'-UUCUCCGAACGUGUCACGUTT-3'.

3'UTR sequence of Egrl $m R N A$. According to the rat EGRI gene (gene ID: 24330), TargetScan was used to predict the miRNAs that may bind to Egr1 mRNA, and analyze their potential binding sites and the context score percentiles.

Reverse transcription-quantitative PCR (RT-qPCR). Total RNA from AR42J cell lines $\left(1 \times 10^{6}\right.$ cells) was isolated using Axygen reagent (Axygen; Corning Inc.), and first strand cDNA was synthesized using ReverTraAce qPCR RT kit (cat. no. FSQ-101; Toyobo Life Science) according to the manufacturer's protocol. qPCR was performed using SYBR ${ }^{\circledR}$ Green Real-time PCR Master Mix (Toyobo Life Science) under the following conditions: $95^{\circ} \mathrm{C}$ for $10 \mathrm{~min}$, followed by 40 cycles of $95^{\circ} \mathrm{C}$ for $2 \mathrm{sec}$ and $60^{\circ} \mathrm{C}$ for $30 \mathrm{sec}$, and a final extension at $72^{\circ} \mathrm{C}$ for $10 \mathrm{~min}$. The primers for Egr1, GAPDH, miR-92a-3p and U6 were synthesized by Guangzhou RiboBio Co., Ltd. The relative expression levels of Egr1 and miR-92a-3p were normalized to endogenous control and were expressed as $2^{-\Delta \Delta C q}(23)$. The RT-qPCR primers were as follows: miR-92a-3p, forward 5'-CGCGTATTGCACTTG TCCC-3', reverse 5'-AGTGCAGGGTCCGAGGTATT-3'; U6, forward 5'-AGAGAAGATTAGCATGGCCCCTG-3', reverse 5'-AGTGCAGGGTCCGAGGTATT-3'; Egr1, forward 5'-ACT GGAGGAGATGATGCTGCTGAG-3', reverse 5'-CCGCTG CTGCTGCTGCTG-3'; and GAPDH, forward 5'-ACAACT TTGGTATCGTGGAAGG-3' and reverse 5'-GCCATCAGC CACAGTTTC-3'.

Western blotting. Cells were lysed using RIPA buffer (cat. no. P0013K; Beyotime Institute of Biotechnology), and the protein concentration was measured using a Bicinchoninic 
A
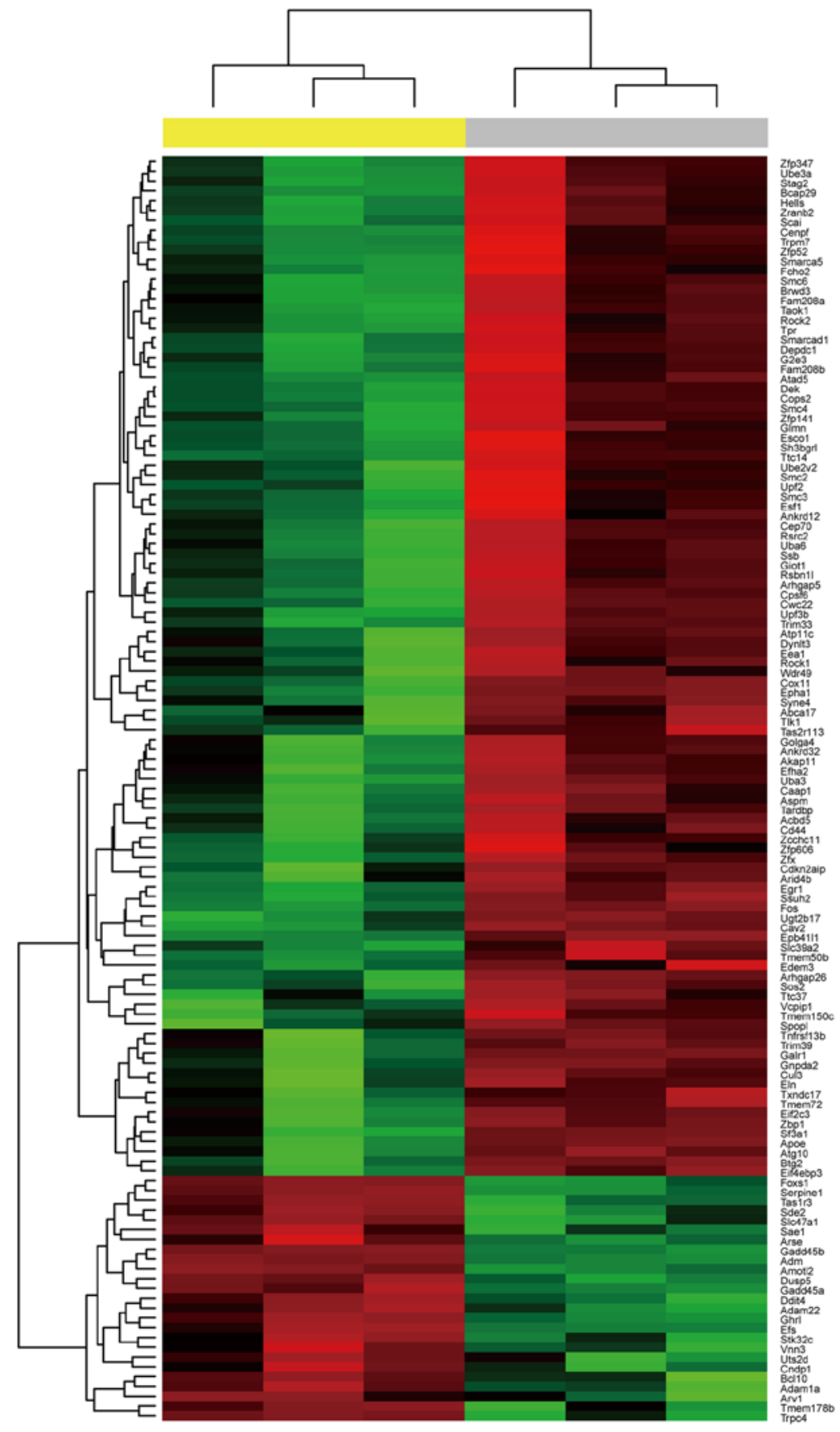

B
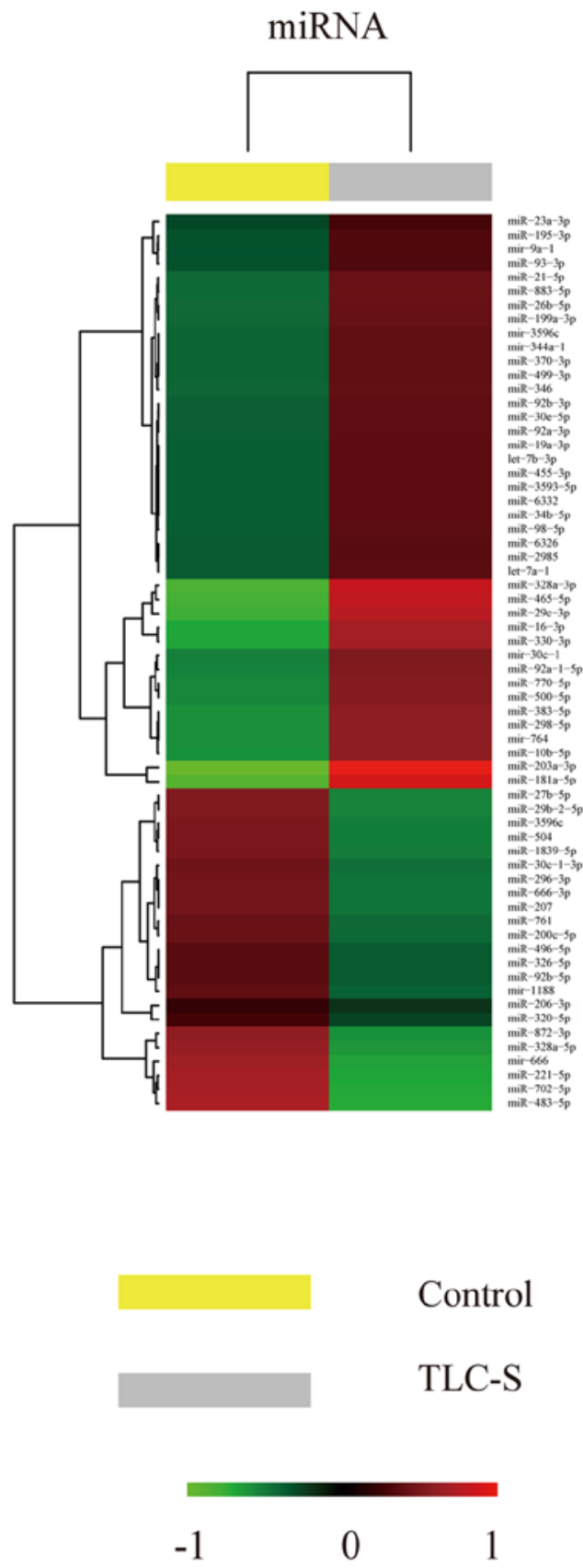

Figure 1. Hierarchically clustered heat map illustrating the changes in mRNA and miRNA expression profiles between TLC-S-treated AR42J cells and control group. Significantly expressed mRNA and miRNA clusters are presented. Red sections represent an increase in expression and green sections represent a decrease in expression. The values -1 and +1 represent Z-score. (A) mRNA hierarchically clustered heat map. (B) miRNA hierarchically clustered heat map. miRNA, microRNA; TLC-S, taurolithocholic acid-3-sulfate.

Acid Protein Assay kit (cat. no. P0011; Beyotime Institute of Biotechnology). Proteins $(40 \mu \mathrm{g})$ were separated via $8 \%$ SDS-PAGE and transferred onto $0.45-\mu \mathrm{m}$ PVDF membranes. Membranes were blocked with in 5\% skimmed milk dissolved in PBST for $1 \mathrm{~h}$ at room temperature. Membranes were incubated with primary antibodies against Egr1 (1:500; cat. no. 4153; Cell Signaling Technology, Inc.) and $\beta$-actin (1:2,000; cat. no. PR-0255; ZSGB-BIO; OriGene Technologies, Inc.) at $4^{\circ} \mathrm{C}$ overnight. Membranes were then incubated with horseradish peroxidase secondary antibody (1:2,000; cat. no. ZB-2301; ZSGB-BIO; OriGene Technologies, Inc.) for $1 \mathrm{~h}$ at room temperature. An ECL kit (cat. no. P0018; Beyotime Biotech, Inc.) was used to detect the signal on the membrane. Data were analyzed by densitometry using Image Lab software (version 2.0.1; Bio-Rad Laboratories, Inc.) and normalized to expression of the internal control $\beta$-actin.

Detection of trypsinogen activation by flow cytometry. Cells $\left(1 \times 10^{6}\right)$ were harvested and centrifuged at $500 \mathrm{x} \mathrm{g}$ for $5 \mathrm{~min}$ at room temperature and the supernatant was discarded. Cell 


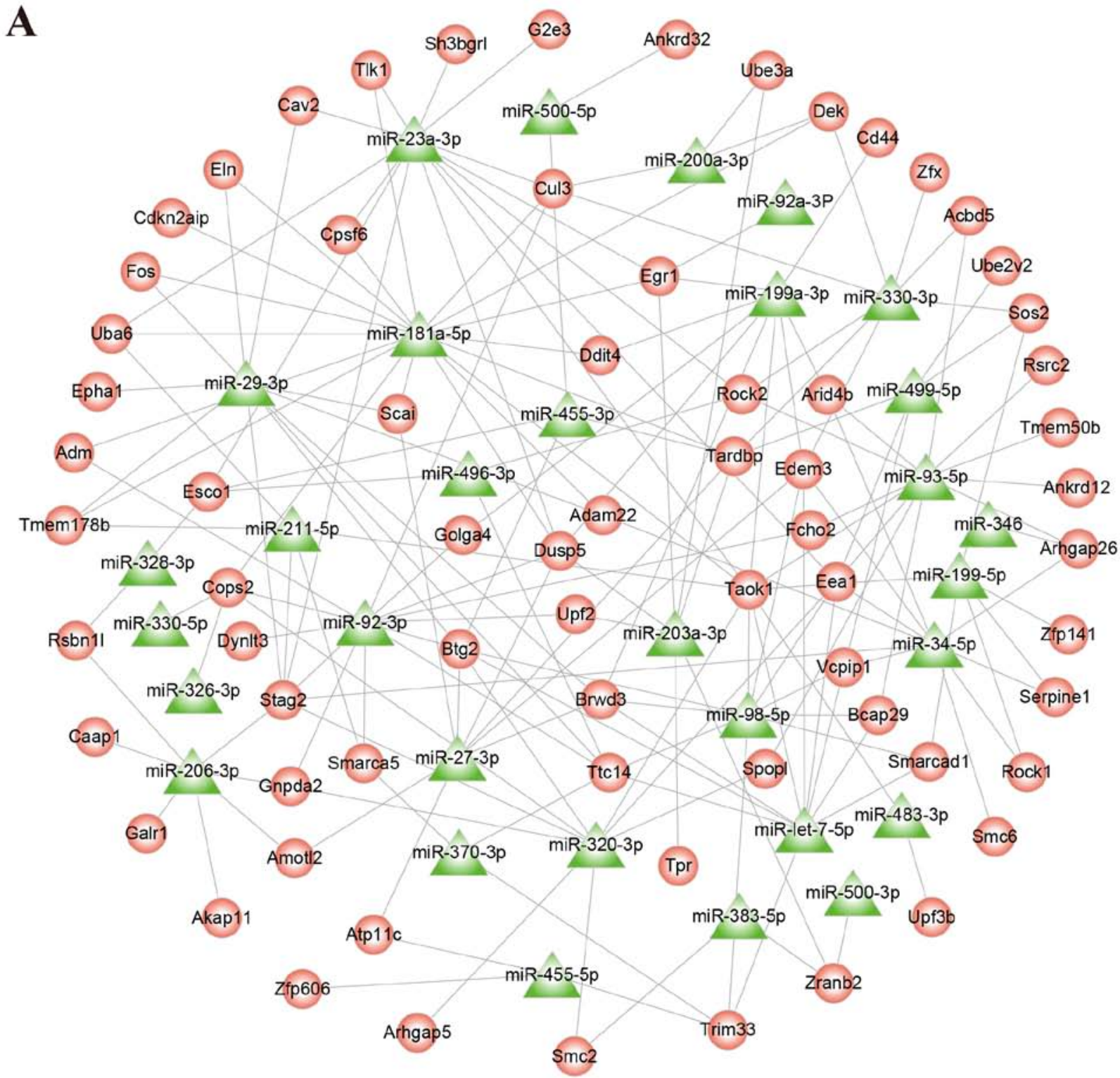

B

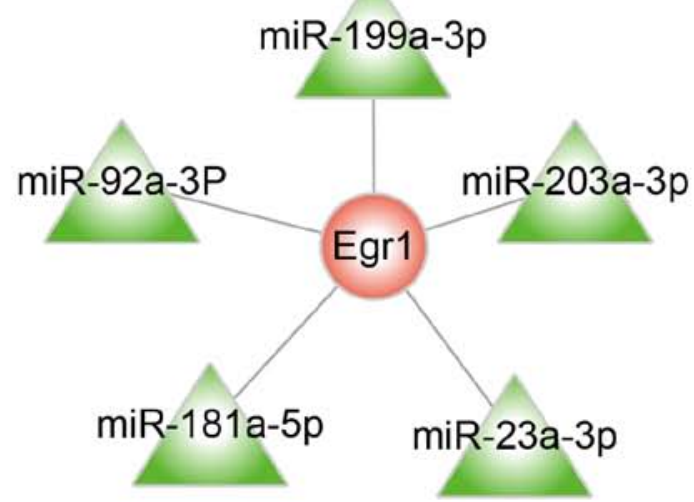

miRNA

mRNA

Figure 2. miRNA-mRNA regulatory network. (A) Representation of the association between mRNA upregulation and miRNA downregulation. (B) Egrl subnetwork. The circular nodes represent mRNA and the triangle nodes represent miRNA. Erg1, early growth response protein 1; miRNA, microRNA.

pellet was washed twice with $1 \mathrm{X}$ HEPES and centrifuged at $500 \mathrm{x} \mathrm{g}$ for $5 \mathrm{~min}$ at room temperature. Cells were then resuspended in BziPAR-Rhodamine 110 (Invitrogen; Thermo Fisher Scientific, Inc.) working solution and allowed to react in the dark at $37^{\circ} \mathrm{C}$ for $20 \mathrm{~min}$. BziPAR-Rhodamine 110 is a trypsin substrate; after enzymatic cleavage, fluorescence is increased (24). After centrifugation at $500 \mathrm{x} \mathrm{g}$ for $5 \mathrm{~min}$ at room temperature, supernatant was discarded and cells were gently 
A
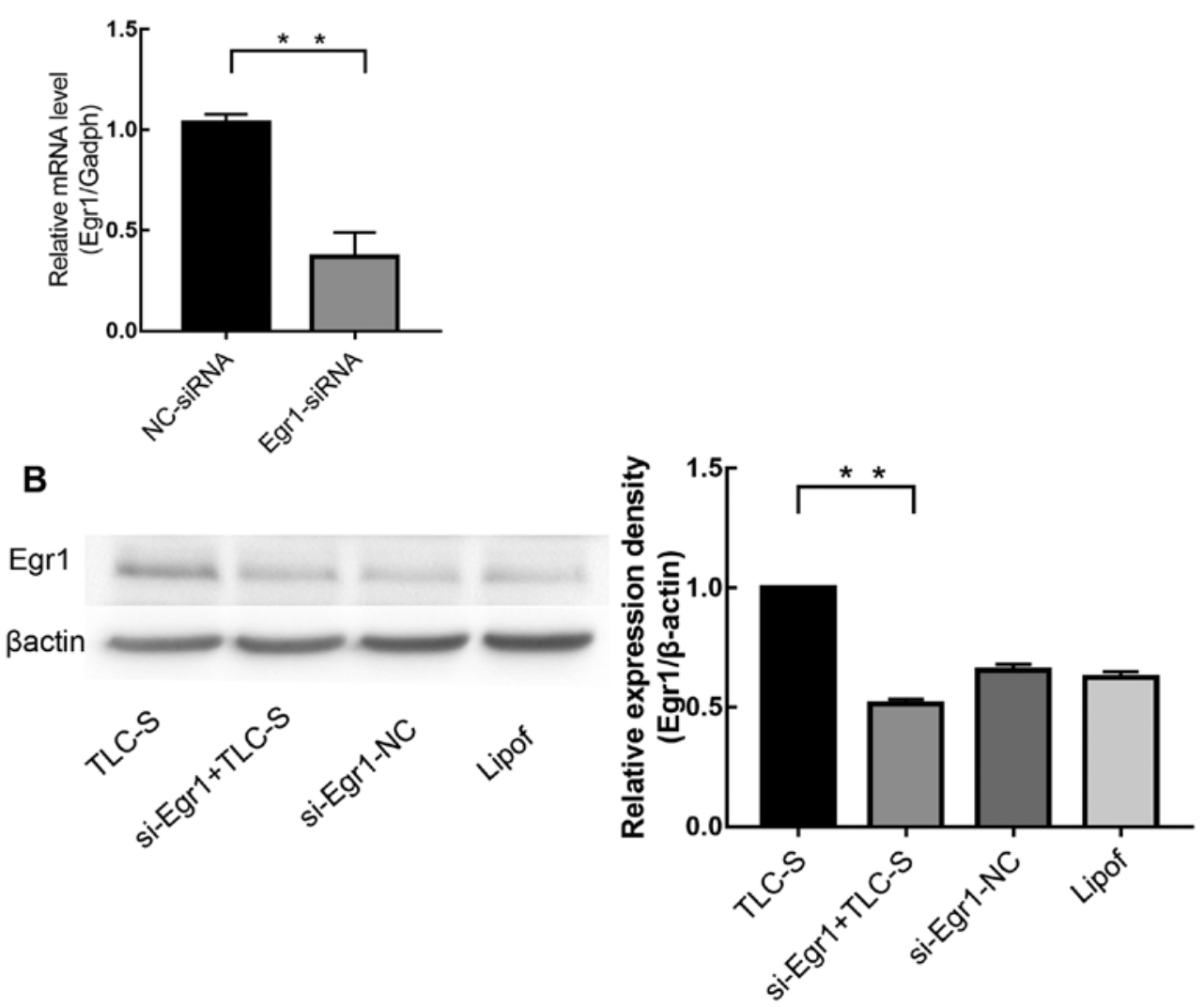

Figure 3. Egr1 expression following transfection. (A) Egrl mRNA levels in AR42J cells following si-Egrl transfection analyzed by reverse transcriptionquantitative PCR. (B) Egrl protein levels in AR42J cells following si-Egr1 transfection analyzed by western blotting. ${ }^{* *} \mathrm{P}<0.01$. Erg1, early growth response protein 1; lipof, lipofectamine; NC, negative control; si, small interfering; TLC-S, taurolithocholic acid-3-sulfate.

resuspended with 1X HEPES and analyzed by flow cytometry (Calibur II, BD Biosciences). The cells were collected using CellQuest software (version 6.0; BD Biosciences), and the experimental data were analyzed using the Kaluza Analysis software program (version 2.1; Beckman Coulter, Inc.).

Statistical analysis. Experiments were repeated at least three times. All data are presented as the mean $\pm \mathrm{SD}$. Comparisons between groups were made using Student's t-test or one-way ANOVA followed by Bonferroni test. Statistical analysis was performed using SPSS 17.0 software (SPSS, Inc.). P $<0.05$ was considered to indicate a statistically significant difference.

\section{Results}

Screening of differentially expressed mRNAs and miRNAs. Analysis of mRNA and miRNA microarrays revealed significant differences in mRNA and miRNA expression levels between TLC-S-treated AR42J cells and control group. In total, 129 mRNAs and 64 miRNAs were found to be differentially expressed (Fig. 1).

Construction of the miRNA-mRNA regulatory network. Based on TargetScan bioinformatics predictions and differentially expressed mRNAs and miRNAs, Cytoscape software was used to construct a regulatory network containing upregulated mRNAs and downregulated miRNAs (Fig. 2A). Through a literature review, the results demonstrated that Egrl was associated with AP. Subsequently, five miRNAs (miR-199a-3p, miR-203a-3p, miR-23a-3p, miR-181a-5p and miR-92a-3p) that exhibited regulatory association with Egrl were identified (Fig. 2B).

si-Egrl transfection efficiency. Following 4-6 h transfection of AR42J cells with si-Egr1, Egr1 expression was analyzed by RT-qPCR (Fig. 3A) and western blotting (Fig. 3B). The results demonstrated that si-Egrl-transfected cells presented significantly reduced Egrl expression level, whereas there was no significant difference between the siRNA-NC group and the lipofectamine-treated group $(\mathrm{P}>0.05)$.

Potential miR-92a-3p binding site was identified in the Egrl 3'UTR sequence. The structure of miR-92a-3p is presented in Fig. 4A. Bioinformatics analysis using TargetScan revealed that the 3'UTR sequence of Egrl contained a potential binding site for miR-92a-3p (Fig. 4B). Furthermore, potential binding sites for miR-181a-5p, miR-203a-3p, miR-199a-3p and miR-23a-3p were also found in the Egrl 3'UTR sequence (Fig. 4C). In addition, the context score percentiles of miR-181a-5p, miR-203a-3p, miR-199a-3p and miR-23a-3p were reduced compared with that of miR-92a-3p, which indicated that miR-92a-3p was more likely to bind Egrl compared with the other miRNAs. The present bioinformatics analysis suggested that miR-92a-3p may regulate Egrl expression. 
$\mathbf{A}$

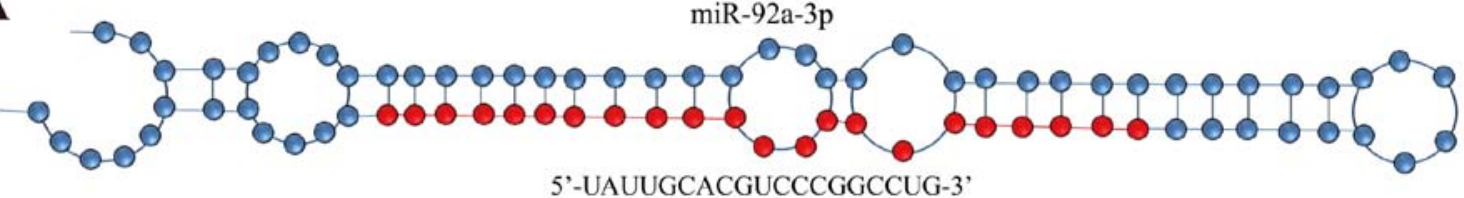

B

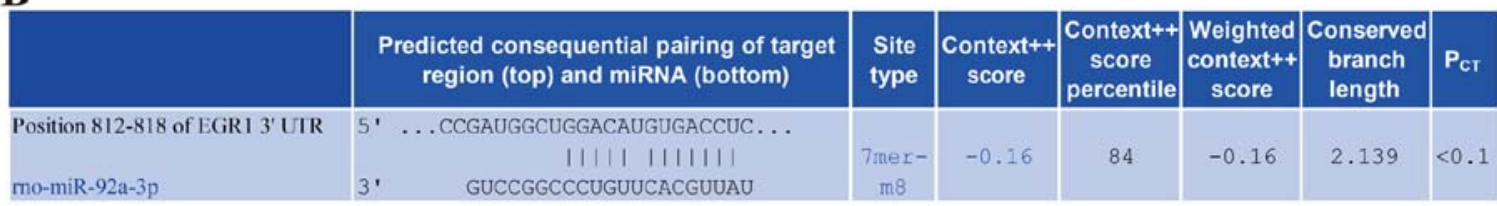

C

\begin{tabular}{|c|c|c|c|c|c|c|c|c|}
\hline & & $\begin{array}{l}\text { Predicted consequential pairing of target } \\
\text { region (top) and miRNA (bottom) }\end{array}$ & $\begin{array}{l}\text { Site } \\
\text { type }\end{array}$ & $\begin{array}{c}\text { Context++ } \\
\text { score }\end{array}$ & $\begin{array}{l}\text { Context++ } \\
\text { score } \\
\text { percentile }\end{array}$ & $\begin{array}{c}\text { Weighted } \\
\text { context++ } \\
\text { score }\end{array}$ & $\begin{array}{c}\text { Conserved } \\
\text { branch } \\
\text { length }\end{array}$ & $\mathbf{P}_{\mathrm{CT}}$ \\
\hline $\begin{array}{l}\text { Position 926-932 of EGRI 3' UTR } \\
\text { mo-miR-181a-5p }\end{array}$ & $5^{\prime}$ & 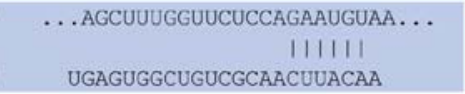 & $\begin{array}{c}7 \text { mer- } \\
\text { A1 }\end{array}$ & -0.12 & 82 & -0.12 & 4.218 & 0.43 \\
\hline $\begin{array}{l}\text { Position 1035-1041 of EGRI 3' UTR } \\
\text { mo-miR-199a-3p }\end{array}$ & $5^{\prime}$ & $\begin{array}{c}\text {... GAAUGCUGCGGUUACCUACUGAG... } \\
1111111 \\
\text { AUUGGUUACACGUCUGAUGACA }\end{array}$ & $\begin{array}{c}7 \text { mer- } \\
\text { A1 }\end{array}$ & 0.14 & 80 & -0.14 & 4.858 & 0.76 \\
\hline $\begin{array}{l}\text { Position } 437-443 \text { of EGR1 3' UTR } \\
\text { mo-miR-23a-3p }\end{array}$ & $5^{\prime}$ & $\begin{array}{c}\text {... CUUGGgGUAUUCUUGAUGUGAAG... } \\
1111\|1\| \\
\text { CCUUUAGGGACCGUUACACUA }\end{array}$ & $\begin{array}{c}7 \text { mer- } \\
\text { A1 }\end{array}$ & -0.06 & 71 & -0.06 & 4.099 & 0.17 \\
\hline $\begin{array}{l}\text { Position } 275-281 \text { of EGR1 3' UTR } \\
\text { mo-miR-203a-3p }\end{array}$ & $5^{\prime}$ & $\begin{array}{c}\text {... UGGUAUUGGAUAAACCAUUUCAG... } \\
\qquad 1111\|1\| \\
\text { GAUCACCAGGAUUUGUAAAGUG }\end{array}$ & $\begin{array}{c}\text { 7mer- } \\
\text { m8 }\end{array}$ & -0.02 & 63 & -0.02 & 2.465 & 0.27 \\
\hline
\end{tabular}

Figure 4. Bioinformatics analysis. (A) Structure of miR-92a-3p. (B) TargetScan analysis indicated that miR-92a-3p contained a sequence complementary to the 3'-UTR of Egr1. (C) Four other miRNAs (miR-181a-5p, miR-199a-3p, miR-23a-3p and miR-203a-3p) contain a sequence complementary to the 3'-UTR of Egr1, and analysis revealed that miR-92a-3p has the highest context score percentile. Erg1, early growth response protein 1; miRNA, microRNA; UTR, untranslated region.

miR-92a-3p downregulates Egrl expression. In order to experimentally confirm the bioinformatics analyses, the present study investigated whether miR-92a-3p could affect Egrl expression in AR42J cells. miR-92a-3p mimic or inhibitor was transfected into AR42J cells to enhance and decrease the effect of miR-92a-3p, respectively. Subsequently, cells were treated with TLC-S, and miR-92a-3p (Fig. 5A) and Egr1 (Fig. 5B) expression were measured by RT-qPCR. As presented in Fig. 5B, compared with the TLC-S group, Egrl expression in the miR-92a-3p mimic group was significantly decreased $(\mathrm{P}<0.01)$. Furthermore, compared with the TLC-S group, Egr1 expression was significantly increased in miR-92a-3p inhibitor group $(\mathrm{P}<0.01)$. There was no significant difference in Egr1 expression between miR-92a-3p mimic-NC group and miR-92a-3p inhibitor-NC group ( $\mathrm{P}>0.05)$. Egr1 protein level was consistent with RT-qPCR results (Fig. 5C and D). These results indicated that miR-92a-3p downregulated Egr1 expression in AR42J cells.

miR-92a-3p regulates trypsinogen activation via Egrl. BziPAR-Rhodamine 110 has been reported to be an excellent substrate for serine proteinases, and results from fluorescence analysis demonstrated that trypsin fluorescence is further increased following enzymatic cleavage of the fluorescent substrates (25). In the present experiment, flow cytometry was used to detect the percentage of green fluorescent cells in order to assess the level of trypsinogen activation. The present results suggested that trypsinogen activation in the miR-92a-3p mimic group was significantly decreased compared with the TLC-S group (Fig. 6). Furthermore, compared with the TLC-S group, the miR-92a-3p inhibitor group exhibited significantly increased trypsinogen activation. To further determine whether miR-92a-3p regulation of trypsinogen activation was mediated by Egr1, AR42J cells were transfected with si-Egr1 and miR-92a-3p inhibitor, and the results demonstrated that the decrease in trypsinogen activation induced by si-Egrl was reversed (Fig. 7). These results suggested that miR-92a-3p may regulate trypsinogen activation via Egrl.

\section{Discussion}

AP is a common acute abdominal disease, the incidence of which has recently increased $(26,27)$. Premature activation of digestive proteases in the pancreas is the first step that leads to autodigestion of pancreatic tissue and therefore to the development of AP. Ohmuraya and Yamamura (28) demonstrated that autophagy accelerates lysosomal hydrolase activation of trypsinogen, which subsequently causes AP, in an autophagy-related protein 5 knockout mice model. Halangk et al (29) used a CTSB-deficient mice model to induce pancreatitis and demonstrated that trypsinogen activity in the pancreas of CTSB knockout mice was $80 \%$ lower than that of wild animals. In addition, the degree of acinar tissue necrosis was $50 \%$ compared with control animals. These previous studies provided the first conclusive evidence indicating that inhibition of trypsinogen activation can reduce the extent of AP. Previous in vitro cell experiments used different treatments (TLC-S, cerulein and TNF- $\alpha$ ) to induce trypsinogen activation or AR42J cell apoptosis in order to elucidate the underlying mechanisms 
A

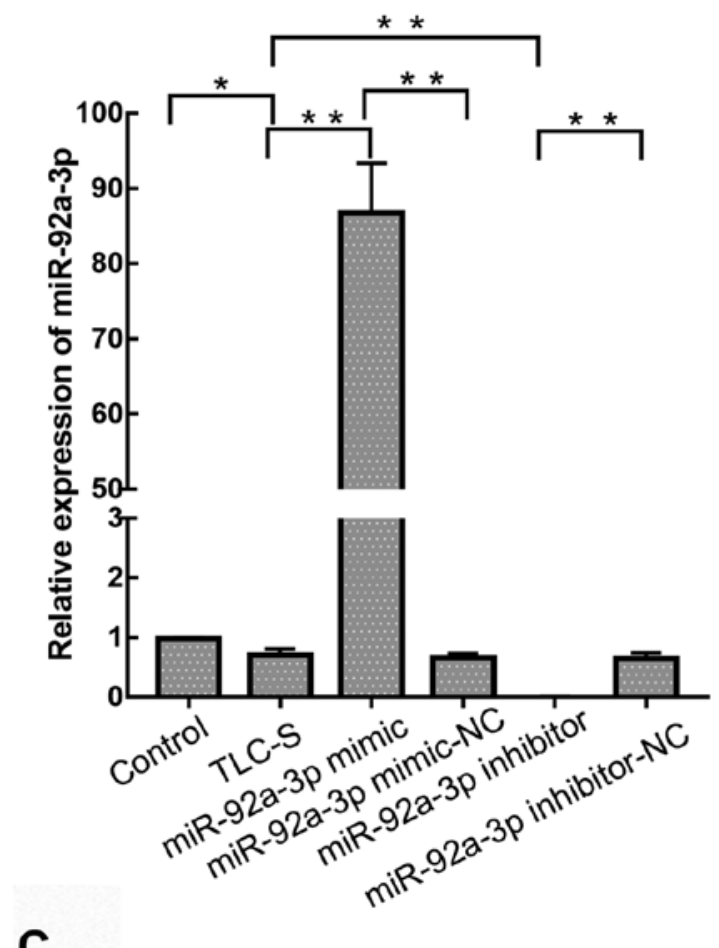

C

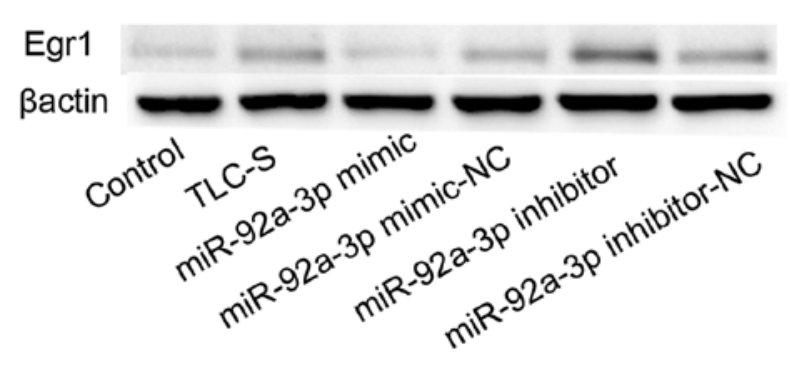

B
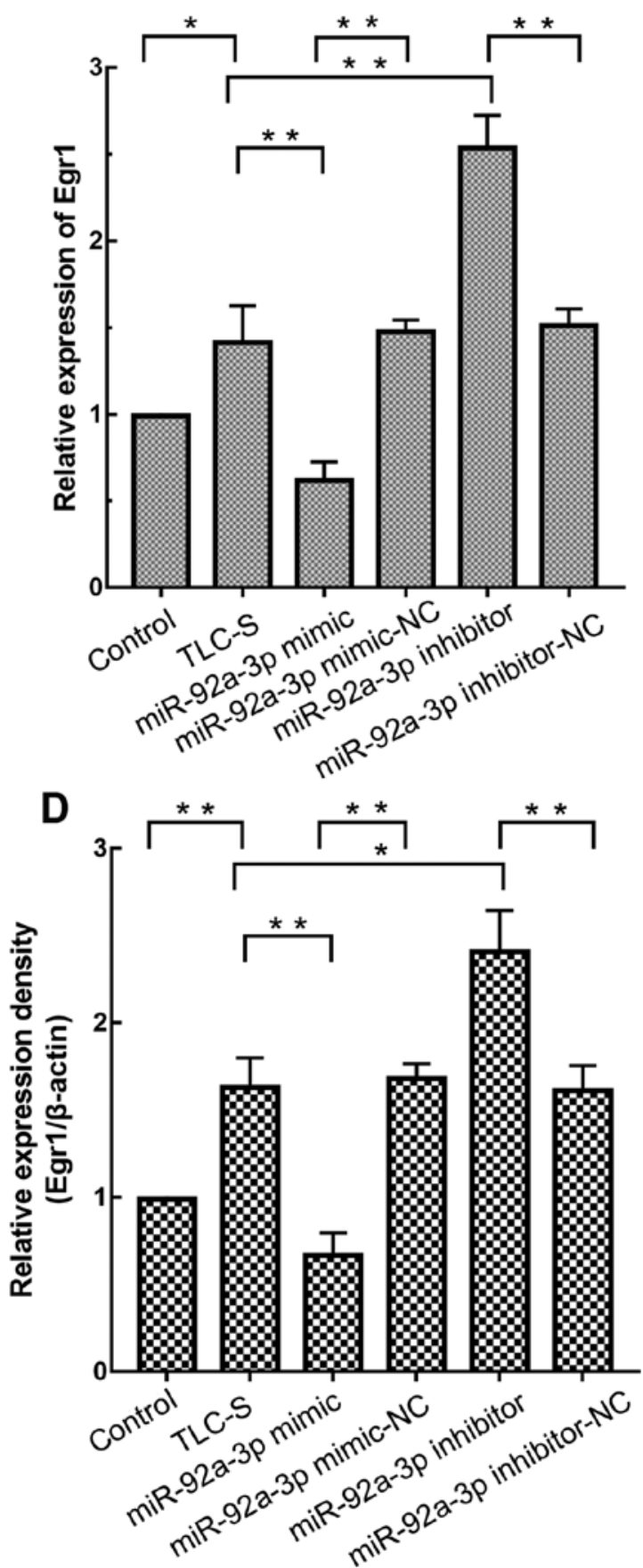

Figure 5. Effects of miR-92a-3p on Egrl expression. miR-92a-3p mimics and inhibitors were transfected into AR42J cells. (A) Relative miR-92a-3p expression level in each group. ${ }^{*} \mathrm{P}<0.05,{ }^{* *} \mathrm{P}<0.01$. (B) Effect of miR-92a-3p mimic and inhibitor on Egr1 mRNA expression levels. ${ }^{*} \mathrm{P}<0.05$, ${ }^{* *} \mathrm{P}<0.01$. (C) Effect of miR-92a-3p mimic and inhibitor on Egr1 protein levels. (D) Egr1 protein levels represent the means \pm SD from three replicates. ${ }^{*} \mathrm{P}<0.05{ }^{* *} \mathrm{P}<0.01$. Erg1, early growth response protein 1; miRNA, microRNA; NC, negative control; TLC-S, taurolithocholic acid-3-sulfate.

of AP development and to determine the genes or pathways of interest $(14,16,30,31)$. Studies using AP animal models will be performed.

In the present study, AR42J cells treated with TLC-S were used to establish an in vitro trypsinogen activation model of AP. Microarray and bioinformatics assays were also used to construct mRNA and miRNA interaction networks based on Egrl as an entry point, and to study the role of miR-92a-3p binding with Egrl in AP.
Egr1 is located on the q23-31 'cytokine aggregation' region of human chromosome 5 and is an early gene that serves crucial roles in regulating cell cycle, proliferation and differentiation, and damage repair (32). Abnormal expression of Egr1 was reported to be associated with various types of disease, including ischaemic injury, atherosclerosis, inflammation, cardiovascular pathogenesis and cancer (33). Egr1 serves a key role in cell damage (34). In unstimulated cells, Egr1 is rarely expressed; however, when cells are 
A
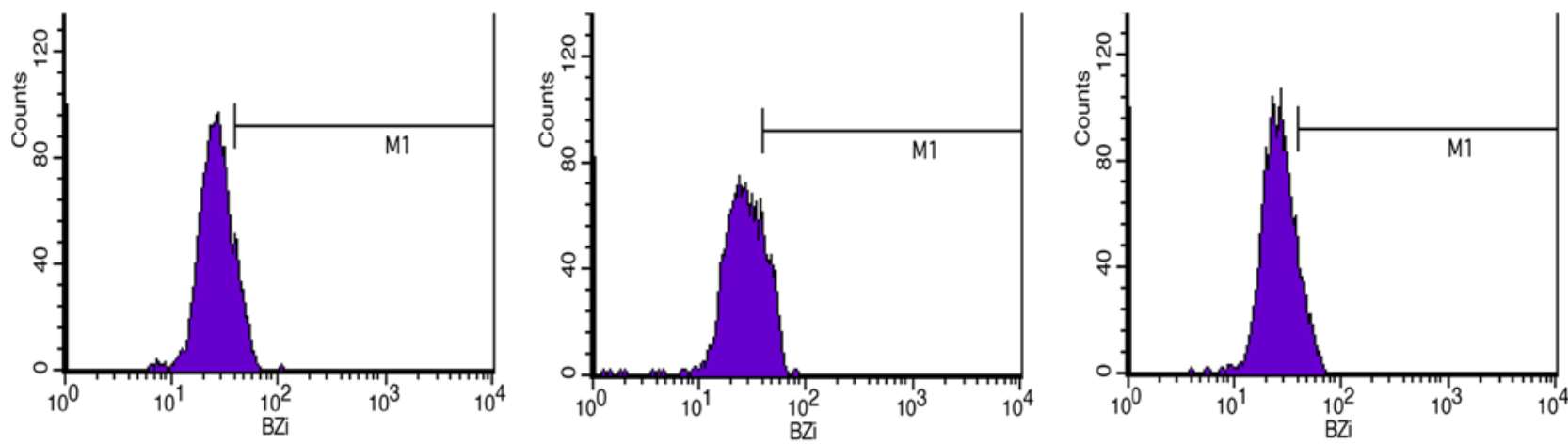

control

TLC-S
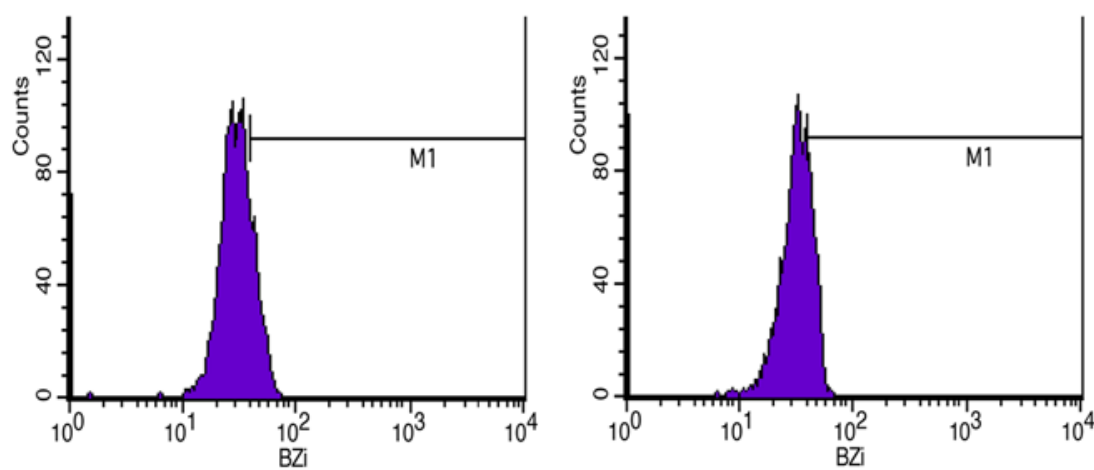

miR-92a-3p mimic
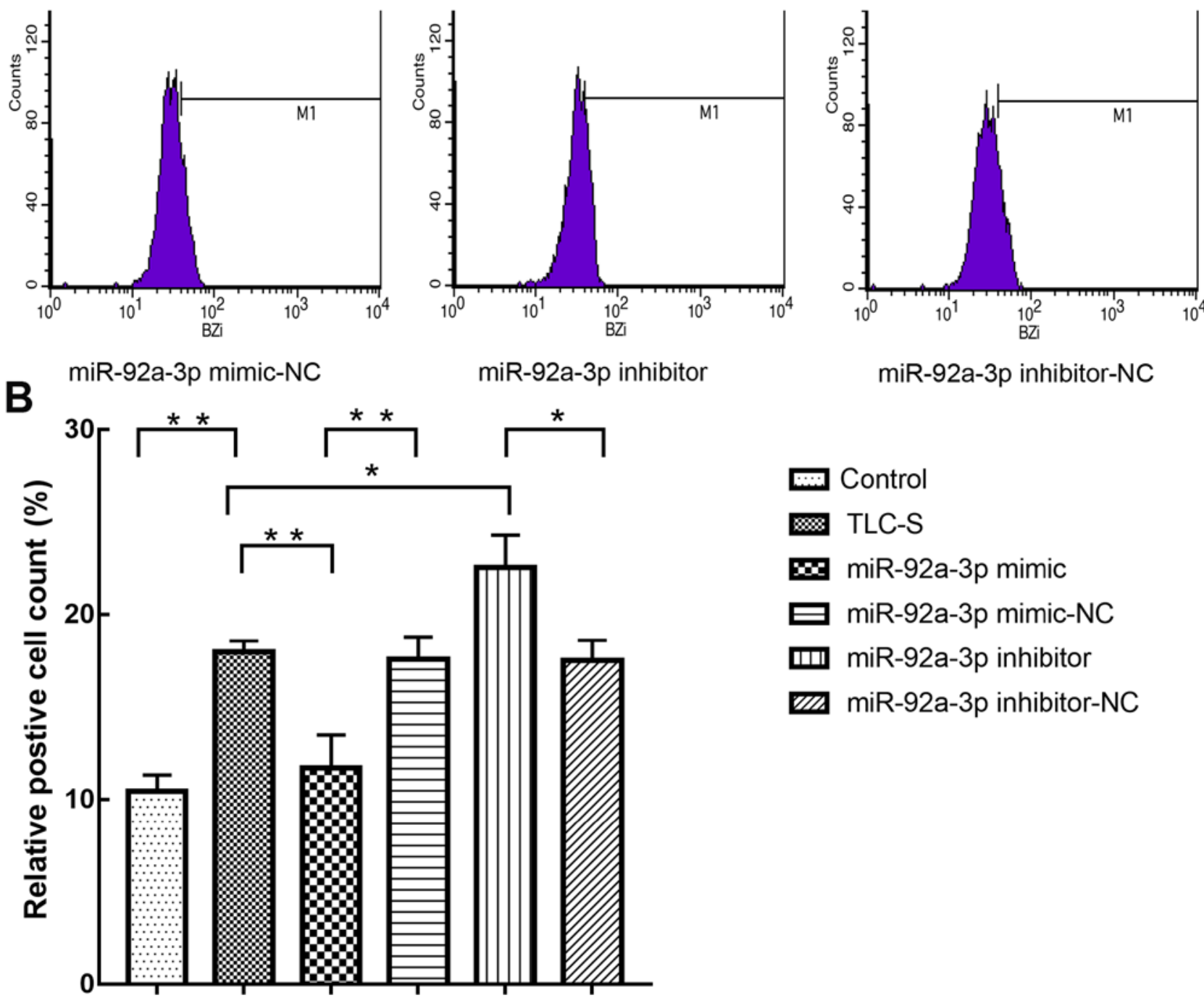

miR-92a-3p inhibitor-NC

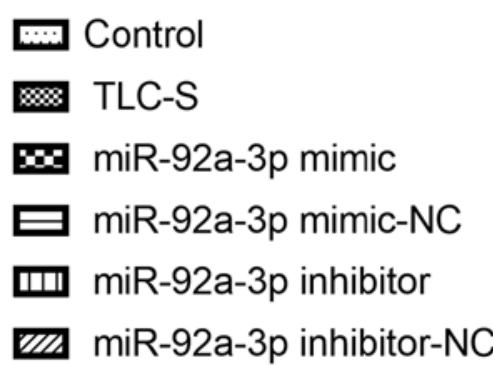

Figure 6. Trypsinogen activation detected by flow cytometry in each group. (A) Flow cytometry results. (B) Quantification of flow cytometry results. * $<0.05$, ${ }^{* *} \mathrm{P}<0.01$. miRNA, microRNA; NC, negative control; TLC-S, taurolithocholic acid-3-sulfate.

stimulated by extracellular signaling molecules (growth factors, hormones and neurotransmitters), Egr1 is immediately synthesized $(35,36)$.

It has been demonstrated that Egr1 is early synthesized in pancreatic acinar cells following AP induction by cerulein injection (14). Sandoval et al (16) used TLC-S to induce AP in rats and AR42J cells and reported that Egr1 is an early proinflammatory gene. Furthermore, the expression of inflammation-associated genes, including monocyte chemoattractant protein 1 , macrophage inflammatory protein 1 and intercellular adhesion molecule 1, and lung inflammation were reduced in Egrl-deficient mice, and it was demonstrated that Egr1 activity can affect the severity of AP (37-39). Stimulation of Egr-1 synthesis is transient, which indicates that cells are adapting to prevent constitutive synthesis of Egr-1. The inhibitory domains NGFI-A binding protein 1 and 2 (NAB1 and 
A
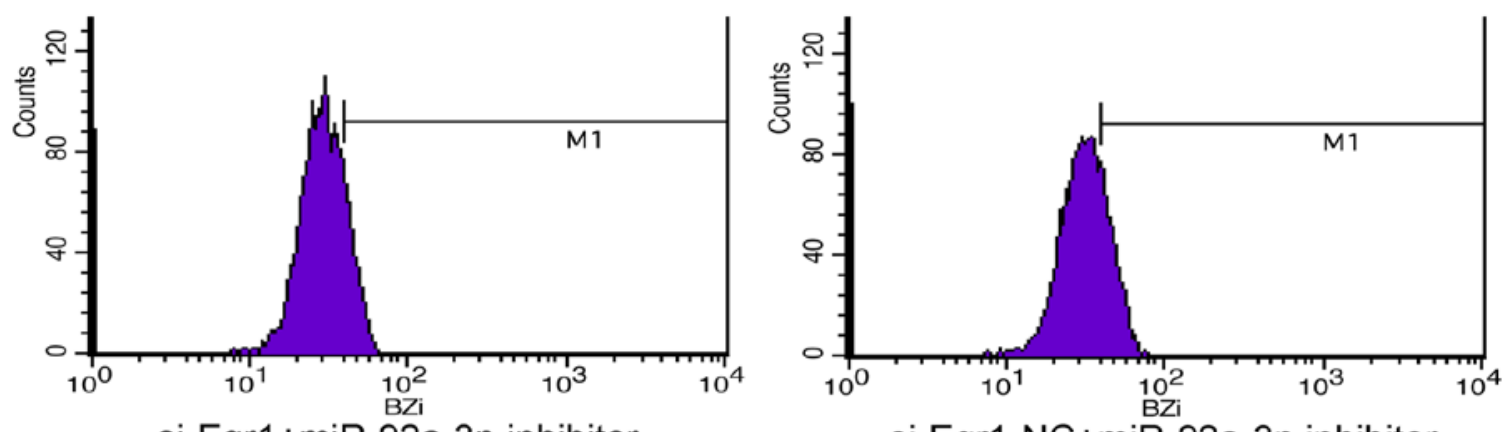

si-Egr1+miR-92a-3p inhibitor

si-Egr1-NC+miR-92a-3p inhibitor
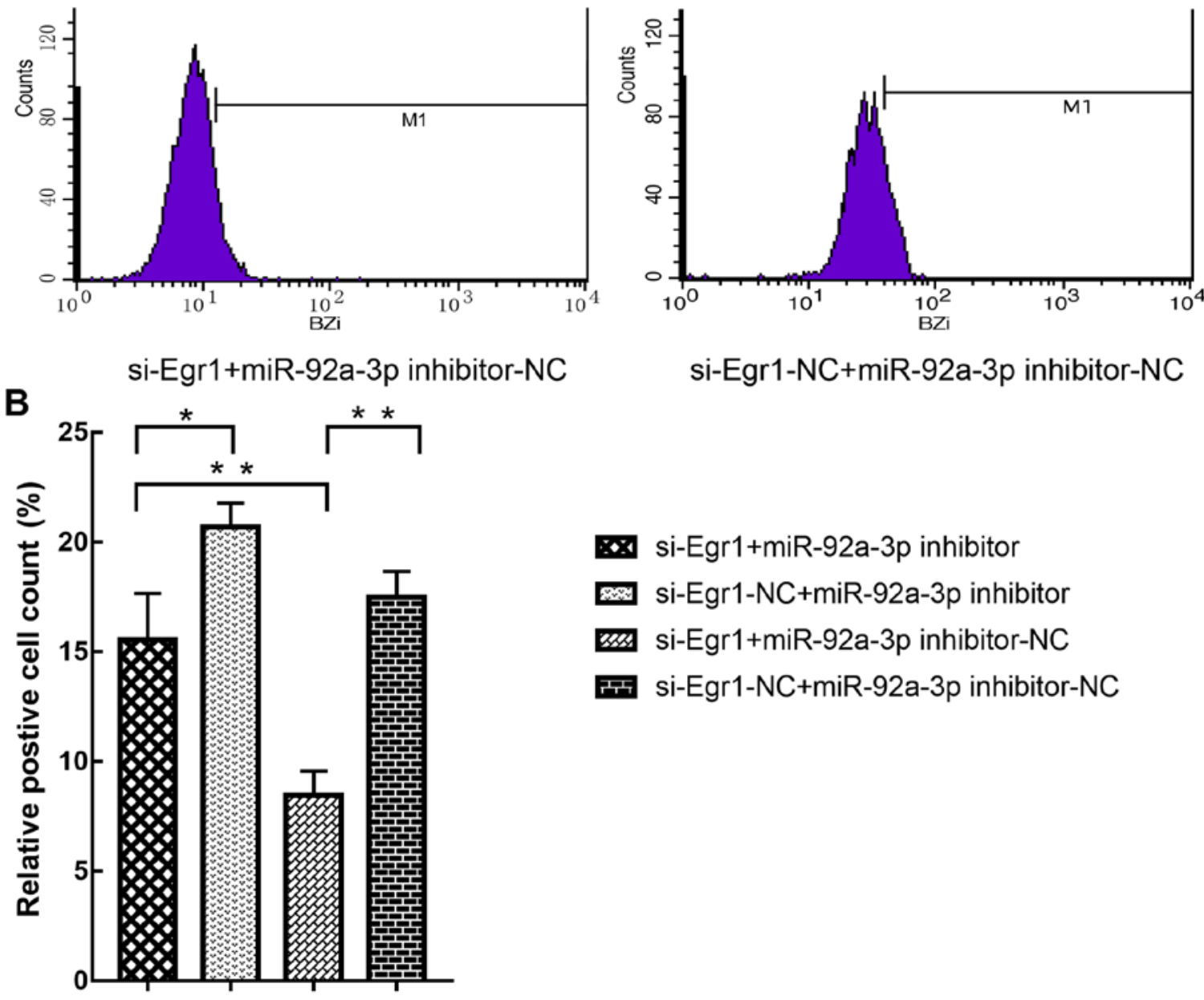

si-Egr1-NC+miR-92a-3p inhibitor-NC

B

si-Egr1+miR-92a-3p inhibitor

si-Egr1-NC+miR-92a-3p inhibitor

si-Egr1+miR-92a-3p inhibitor-NC

两

si-Egr1-NC+miR-92a-3p inhibitor-NC

Figure 7. Trypsinogen activation was detected by flow cytometry following cotransfection of si-Egr1 and miR-92 mimic or inhibitor. (A) Flow cytometry results. (B) Quantification of flow cytometry results. ${ }^{*} \mathrm{P}<0.05,{ }^{* * *} \mathrm{P}<0.01$. Erg1, early growth response protein 1; miRNA, microRNA; NC, negative control; si, small interfering; miR, microRNA.

NAB2) are comprised between the Egr1 activation domain and the DNA binding domain. Both NAB1 and NAB2 block the biological activity of Egr-1 $(40,41)$. Achieving Egr-1 overexpression has therefore been a challenge, and experimental methods attempting to do so were not always successful (42). In addition, the results of the present study indicated that miR-92a-3p may regulate trypsinogen activation via Egr1, suggesting the importance of Egrl in AP.

Previous work from our laboratory suggested that high Egr1 expression is associated with the development of AP and that AR42J cell transfection with si-Egr1 reduces trypsinogen activation (unpublished data). By using microarray analysis and literature review, the present study demonstrated that Egrl was associated with AP. Furthermore, microarrays and bioinformatics analyses demonstrated that miR-92a-3p regulated Egrl expression. It has been demonstrated that miR-92a-3p is associated with cancer invasion (43) and insulin secretion (44); however, its role in pancreatitis has not yet been reported. In the present study, the results from miRNA microarray and RT-qPCR demonstrated that miR-92a-3p levels were decreased in the trypsinogen activation in vitro model of AP. In addition, miR-92a-3p mimic and inhibitor were used to study the function of miR-92a-3p. The present results demonstrated that trypsinogen activation was significantly increased in the 
miR-92a-3p mimic group but was significantly decreased in the miR-92a-3p inhibitor group.

Present bioinformatics analyses suggested that Egr1 may be a target gene of miR-92a-3p. The results of the present study suggested that AR42J cells transfected with miR-92a-3p mimics expressed low Egr1 mRNA and protein levels, whereas miR-92a-3p inhibitors induced overexpression of Egr1 mRNA and protein levels. These data suggested that miR-92a-3p overexpression may downregulate Egr1 expression. Furthermore, the effect of AR42J cell transfection with si-Egr1 and miR-92a-3p inhibitor on trypsinogen activation were investigated. The present results suggested that transfection with miR-92a-3p inhibitor could reverse the si-Egrl-induced decrease in trypsinogen activation. The present findings suggested that miR-92a-3p may regulate Egr1 expression, reducing the transcription and translation levels of trypsinogen-associated genes in AR42J cells. Further studies are required to investigate the role and underlying mechanisms of genes that could potentially interact with Egr1. In conclusion, the results of the present study suggested that miR-92a-3p was significantly reduced in AR42J cells treated with TLC-S compared with control group. The present data indicated that a decrease in miR-92a-3p may not completely inhibit Egr1 gene and may lead to trypsinogen activation.

\section{Acknowledgements}

The authors would like to thank Ms Xinyi Liu (Harbin Medical University) and Ms Xuanxuan Zou (University of Chinese Academy of Sciences) for their help with bioinformatics analysis.

\section{Funding}

The present work was supported by the National Natural Science Foundation of China (grant no. 81570581).

\section{Availability of data and materials}

The datasets used and/or analyzed during the current study are available from the corresponding author on reasonable request.

\section{Authors' contributions}

DX and WZ designed the study. BG and YH provided study material. YZ, ZL, DZ and BM performed the experiments and assembled the data. XZ, BG, YH and YZ analyzed and interpreted the data. $\mathrm{XZ}$ performed experiments and wrote the manuscript. All authors read and approved the final version of the manuscript.

\section{Ethics approval and consent to participate}

Not applicable.

\section{Patient consent for publication}

Not applicable.

\section{Competing interests}

The authors declare that they have no competing interests.

\section{References}

1. Krishna SG, Kruger AJ, Patel N, Hinton A, Yadav D and Conwell DL: Cholecystectomy during index admission for acute biliary pancreatitis lowers 30-day readmission rates. Pancreas 47: 996-1002, 2018.

2. Pandol SJ, Saluja AK, Imrie CW and Banks PA: Acute pancreatitis: Bench to the bedside. Gastroenterology 132: 1127-1151, 2007.

3. Gao B, Wang D, Sun W, Meng X, Zhang W and Xue D: Differentially expressed microRNA identification and target gene function analysis in starvation-induced autophagy of AR42J pancreatic acinar cells. Mol Med Rep 14: 590-598, 2016.

4. Dawra R, Sah RP, Dudeja V, Rishi L, Talukdar R, Garg P and Saluja AK: Intra-acinar trypsinogen activation mediates early stages of pancreatic injury but not inflammation in mice with acute pancreatitis. Gastroenterology 141: 2210-2217.e2, 2011.

5. Sato H, Siow RC, Bartlett S, Taketani S, Ishii T, Bannai S and Mann GE: Expression of stress proteins heme oxygenase-1 and -2 in acute pancreatitis and pancreatic islet betaTC 3 and acinar AR42J cells. FEBS Lett 405: 219-223, 1997.

6. Ma B, Wu L, Lu M, Gao B, Qiao X, Sun B, Xue D and Zhang W: Differentially expressed kinase genes associated with trypsinogen activation in rat pancreatic acinar cells treated with taurolithocholic acid 3-sulfate. Mol Med Rep 7: 1591-1596, 2013.

7. Yang Z, Yang W, Lu M, Li Z, Qiao X, Sun B, Zhang W and Xue D: Role of the c-Jun N-terminal kinase signaling pathway in the activation of trypsinogen in rat pancreatic acinar cells. Int $J$ Mol Med 41: 1119-1126, 2018.

8. Zhao Q, Wei Y, Pandol SJ, Li L and Habtezion A: STING signaling promotes inflammation in experimental acute pancreatitis. Gastroenterology 154: 1822-1835.e2, 2018.

9. Liu Y, Chen XD, Yu J, Chi JL, Long FW, Yang HW, Chen KL, Lv ZY, Zhou B, Peng ZH, et al: Deletion Of XIAP reduces the severity of acute pancreatitis via regulation of cell death and nuclear factor- $\kappa$ B activity. Cell Death Dis 8: e2685, 2017.

10. Kowalik AS, Johnson CL, Chadi SA, Weston JY, Fazio EN and Pin CL: Mice lacking the transcription factor Mist1 exhibit an altered stress response and increased sensitivity to caerulein-induced pancreatitis. Am J Physiol Gastrointest Liver Physiol 292: G1123-G1132, 2007.

11. Sendler M, Weiss FU, Golchert J, Homuth G, van den Brandt C, Mahajan UM, Partecke LI, Döring P, Gukovsky I, Gukovskaya AS, et al: Cathepsin B-mediated activation of trypsinogen in endocytosing macrophages increases severity of pancreatitis in mice. Gastroenterology 154: 704-718.e10, 2018.

12. An F, Zhan Q, Xia M, Jiang L, Lu G, Huang M, Guo J and Liu S: From moderately severe to severe hypertriglyceridemia induced acute pancreatitis: Circulating miRNAs play role as potential biomarkers. PLoS One 9: e111058, 2014.

13. Gashler A and Sukhatme VP: Early growth response protein 1 (Egr-1): prototype of a zinc-finger family of transcription factors Prog Nucleic Acid Res Mol Biol 50: 191-224, 1995.

14. Kaufmann A, Rössler OG and Thiel G: Expression of the transcription factor Egr-1 in pancreatic acinar cells following stimulation of cholecystokinin or Gaq-coupled designer receptors. Cell Physiol Biochem 33: 1411-1425, 2014.

15. Zhan X, Wan J, Zhang G, Song L, Gui F, Zhang Y, Li Y, Guo J, Dawra RK, Saluja AK, et al: Elevated intracellular trypsin exacerbates acute pancreatitis and chronic pancreatitis in mice. Am J Physiol Gastrointest Liver Physiol 316: G816-G825, 2019.

16. Sandoval J, Pereda J, Pérez S, Finamor I, Vallet-Sánchez A, Rodríguez JL, Franco L, Sastre J and López-Rodas G: Epigenetic regulation of early- and late-response genes in acute pancreatitis. J Immunol 197: 4137-4150, 2016.

17. Bartel DP: MicroRNAs: Target recognition and regulatory functions. Cell 136: 215-233, 2009.

18. Zhang J, Ning $X$, Cui $W$, Bi $M$, Zhang $D$ and Zhang J: Transforming growth factor (TGF)- $\beta$-induced microRNA-216a promotes acute pancreatitis via Akt and TGF- $\beta$ pathway in mice. Dig Dis Sci 60: 127-135, 2015.

19. Tian R, Wang RL, Xie H, Jin W and Yu KL: Overexpressed miRNA-155 dysregulates intestinal epithelial apical junctional complex in severe acute pancreatitis. World J Gastroenterol 19: 8282-8291, 2013. 
20. Ambros V: MicroRNAs and developmental timing. Curr Opin Genet Dev 21: 511-517, 2011.

21. Gerasimenko JV, Flowerdew SE, Voronina SG, Sukhomlin TK, Tepikin AV, Petersen $\mathrm{OH}$ and Gerasimenko OV: Bile acids induce $\mathrm{Ca}^{2+}$ release from both the endoplasmic reticulum and acidic intracellular calcium stores through activation of inositol trisphosphate receptors and ryanodine receptors. J Biol Chem 281: 40154-40163, 2006.

22. Voronina SG, Barrow SL, Gerasimenko OV, Petersen OH and Tepikin AV: Effects of secretagogues and bile acids on mitochondrial membrane potential of pancreatic acinar cells: Comparison of different modes of evaluating DeltaPsim. J Biol Chem 279: 27327-27338, 2004.

23. Livak KJ and Schmittgen TD: Analysis of relative gene expression data using real-time quantitative PCR and the 2(-Delta Delta C(T)) method. Methods 25: 402-408, 2001.

24. Song Z, Huang Y, Liu C, Lu M, Li Z, Sun B, Zhang W and Xue D: miR-352 participates in the regulation of trypsinogen activation in pancreatic acinar cells by influencing the function of autophagic lysosomes. Oncotarget 9: 10868-10879, 2018.

25. Sherwood MW, Prior IA, Voronina SG, Barrow SL, Woodsmith JD, Gerasimenko OV, Petersen $\mathrm{OH}$ and Tepikin AV: Activation of trypsinogen in large endocytic vacuoles of pancreatic acinar cells. Proc Natl Acad Sci USA 104: 5674-5679, 2007.

26. Vaz J, Akbarshahi H and Andersson R: Controversial role of toll-like receptors in acute pancreatitis. World J Gastroenterol 19: 616-630, 2013.

27. Kylänpää L, Rakonczay Z Jr and O'Reilly DA: The clinical course of acute pancreatitis and the inflammatory mediators that drive it. Int J Inflam 2012: 360685, 2012.

28. Ohmuraya $\mathrm{M}$ and Yamamura K: Autophagy and acute pancreatitis: A novel autophagy theory for trypsinogen activation. Autophagy 4: 1060-1062,2008.

29. Halangk W, Lerch MM, Brandt-Nedelev B, Roth W, Ruthenbuerger M, Reinheckel T, Domschke W, Lippert H, Peters C and Deussing J: Role of cathepsin B in intracellular trypsinogen activation and the onset of acute pancreatitis. J Clin Invest 106: 773-781, 2000.

30. Chen WD, Zhang JL, Wang XY, Hu ZW and Qian YB: The JAK2/STAT3 signaling pathway is required for inflammation and cell death induced by cerulein in AR42J cells. Eur Rev Med Pharmacol Sci 23: 1770-1777, 2019.

31. Meng S, Wang H, Xue D and Zhang W: Screening and validation of differentially expressed extracellular miRNAs in acute pancreatitis. Mol Med Rep 16: 6412-6418, 2017.

32. Sukhatme VP, Cao XM, Chang LC, Tsai-Morris $\mathrm{CH}$, Stamenkovich D, Ferreira PC, Cohen DR, Edwards SA, Shows TB, Curran T, et al: A zinc finger-encoding gene coregulated with c-fos during growth and differentiation, and after cellular depolarization. Cell 53: 37-43, 1988.
33. Yan L, Wang Y, Liang J, Liu Z, Sun X and Cai K: MiR-301b promotes the proliferation, mobility, and epithelial-to-mesenchymal transition of bladder cancer cells by targeting EGR1. Biochem Cell Biol 95: 571-577, 2017.

34. Yan SF, Fujita T, Lu J, Okada K, Shan Zou Y, Mackman N, Pinsky DJ and Stern DM: Egr-1, a master switch coordinating upregulation of divergent gene families underlying ischemic stress. Nat Med 6: 1355-1361, 2000.

35. Thiel $\mathrm{G}$ and Cibelli G: Regulation of life and death by the zinc finger transcription factor Egr-1. J Cell Physiol 193: 287-292, 2002.

36. Alagappan D, Balan M, Jiang Y, Cohen RB, Kotenko SV and Levison SW: Egr-1 is a critical regulator of EGF-receptor-mediated expansion of subventricular zone neural stem cells and progenitors during recovery from hypoxia-hypoglycemia. ASN Neuro 5: 183-193, 2013.

37. Ji B, Chen XQ, Misek DE, Kuick R, Hanash S, Ernst S, Najarian R and Logsdon CD: Pancreatic gene expression during the initiation of acute pancreatitis: identification of EGR-1 as a key regulator. Physiol Genomics 14: 59-72, 2003.

38. Wan H, Yuan Y, Liu J and Chen G: Pioglitazone, a PPAR- $\gamma$ activator, attenuates the severity of cerulein-induced acute pancreatitis by modulating early growth response-1 transcription factor. Transl Res 160: 153-161, 2012.

39. Gong LB, He L, Liu Y, Chen XQ and Jiang B: Expression of early growth response factor-1 in rats with cerulein-induced acute pancreatitis and its significance. World J Gastroenterol 11: 5022-5024, 2005.

40. Russo MW, Sevetson BR and Milbrandt J: Identification of NAB1, a repressor of NGFI-A- and Krox20-mediated transcription. Proc Natl Acad Sci USA 92: 6873-6877, 1995.

41. Svaren J, Sevetson BR, Apel ED, Zimonjic DB, Popescu NC and Milbrandt J: NAB2, a corepressor of NGFI-A (Egr-1) and Krox20, is induced by proliferative and differentiative stimuli. Mol Cell Biol 16: 3545-3553, 1996.

42. Qu Z, Wolfraim LA, Svaren J, Ehrengruber MU, Davidson N and Milbrandt J: The transcriptional corepressor NAB2 inhibits NGF-induced differentiation of PC12 cells. J Cell Biol 142: 1075-1082, 1998

43. Zhang G, Li S, Lu J, Ge Y, Wang Q, Ma G, Zhao Q, Wu D, Gong W, Du M, et al: LncRNA MT1JP functions as a ceRNA in regulating FBXW7 through competitively binding to miR-92a-3p in gastric cancer. Mol Cancer 17: 87, 2018.

44. Setyowati Karolina D, Sepramaniam S, Tan HZ, Armugam A and Jeyaseelan K: miR-25 and miR-92a regulate insulin I biosynthesis in rats. RNA Biol 10: 1365-1378, 2013.

This work is licensed under a Creative Commons Attribution 4.0 International (CC BY-NC 4.0) License 